\title{
Severe methotrexate toxicity after treatment for ectopic pregnancy: A case report
}

\section{Ektopik gebelik tedavisi sonrası ağır metotreksat toksisitesi: Olgu sunumu}

\author{
Sunullah Soysal, Gökçe Anık İlhan, Mehmet Vural, Begüm Yıldızhan \\ Marmara University Faculty of Medicine, Department of Obstetrics and Gynecology, İstanbul, Turkey
}

\begin{abstract}
Severe methotrexate toxicity due to medical treatment of an ectopic pregnancy is presented. The feasibility of low-dose use and success of methotrexate makes it the first drug in the medical treatment of ectopic pregnancies. Besides its advantages, it should be used with caution and severe toxicity should be kept in mind.
\end{abstract}

Keywords: Methotrexate, pregnancy, ectopic, toxicity

$\ddot{O} z$

Bir ektopik gebelik olgusunun medikal tedavisi sonrası ağır metotreksat toksisitesi sunulmaktadır. Düşük dozda kullanılması, kolay kullanımı ve başarısı, metotreksatı ektopik gebelik olgularının medikal tedavisinde ilk seçenek ilaç yapmaktadır. Avantajları yanında kullanımı esnasında ağır toksisite akılda tutularak dikkatle kullanılmalıdır.

Anahtar Kelimeler: Metotreksat, gebelik, ektopik, toksisite

\section{Introduction}

Ectopic pregnancy is a serious condition in gynecologic practice. Treatment options for ectopic pregnancy include surgical treatment, expectant management, and medical treatment. Methotrexate (MTX) treatment is preferred for its fewer adverse effects and cost effectiveness $(1)$.

MTX is a folic acid antagonist and is generally used for the treatment of malignancies, autoimmune diseases, and ectopic pregnancies(2). The inhibitory effect on DNA synthesis of MTX is the rationale in the treatment of ectopic pregnancy in which the target is trophoblasts and fetal cells. Ninety percent of MTX given intravenously undergoes renal excretion without any change within 24 hours(3). Low-dose use of MTX gives freedom to a physician to use it frequently in the treatment of ectopic pregnancies. MTX treatment has two protocols; single dose and multiple dose regimens. The single injection of the drug, less follow-up time, lower cost, and no requirement for folinic acid use makes the single-dose protocol the most preferred. MTX is given $50 \mathrm{mg} / \mathrm{m}^{2}$ intramuscularly. Levels of beta-human chorionic gonadotropin ( $\beta$-hCG) are measured on the $4^{\text {th }}$ and $7^{\text {th }}$ day of treatment. A second dose is not needed if the decrease in $\beta$-hCG levels is more than $15 \%$ between days 4 and 7 . A second dose of MTX is needed in $15-20 \%$ of cases and only $1 \%$ of women who receive the single-dose protocol require a third dose(4-6). Adverse effects are generally mild and self-limited; the most common are stomatitis and conjunctivitis. Rare adverse effects include gastritis, enteritis, dermatitis, pneumonitis, alopecia, elevated liver enzymes, and bone marrow suppression. Approximately 30 percent of patients on the single-dose protocol have adverse effects; this rate is lower for patients on multi-dose regimens (40\%)(7).

Renal and hepatic diseases, immunodeficiency, active pulmonary disease, and peptic ulcer disease are contraindications for MTX treatment ${ }^{(8-10)}$. Herein, an otherwise healthy woman who had a severe adverse event with low-dose MTX treatment is presented.

\section{Case Report}

A gravida 3 woman aged 38 years was admitted to our hospital with symptoms of pelvic pain, diarrhea, and oral lesions. She had MTX $\left(50 \mathrm{mg} / \mathrm{m}^{2}\right)$ treatment when her $\beta$-hCG level was

Address for Correspondence/Yazıșma Adresi: Mehmet Vural, MD,

Marmara University Faculty of Medicine, Department of Obstetrics and Gynecology, İstanbul, Turkey

Phone: +90 5322559575 E-mail: drmvural@yahoo.com

Received /Geliş Tarihi: 26.06.2016 Accepted/Kabul Tarihi: 20.07.2016

${ }^{\oplus}$ Copyright 2016 by Turkish Society of Obstetrics and Gynecology

Turkish Journal of Obstetrics and Gynecology published by Galenos Yaymevi. 
$2279 \mathrm{mIU} / \mathrm{mL}$. Seven days after the first dose, a second dose of MTX treatment was given due to elevated $\beta$-hCG (2304 $\mathrm{mIU} / \mathrm{mL}$ ) and an ultrasound finding of a $2-\mathrm{cm}$ gestational sac in the right fallopian tube. On day 4 of the second dose, emergency laparoscopic salpingectomy was performed for tubal rupture with hemorrhage. She was discharged from hospital on the first postoperative day and readmitted on the second day with bloody diarrhea (ten times a day), oral lesions, and macular rush on the scalp, neck, and chest regions. No remarkable details were noted in her medical history except MTX treatment. In the physical examination, she was pale and her vital signs and body temperature were in the normal range, and a macular rash on the chest, neck and scalp area (Figure 1) and mucositis in oral mucosa were detected (Figure 2). A blood count revealed hemoglobin $(\mathrm{Hb})$ level of $6.4 \mathrm{gr} / \mathrm{dL}$, the white blood cells number was $2000 / \mu \mathrm{L}$, creatinine was $1.76 \mathrm{mg} / \mathrm{dL}$, $\beta$-hcg level was $91 \mathrm{mIu} / \mathrm{mL}$. During the clinical follow-up, the general condition of the patient deteriorated. On the same day,

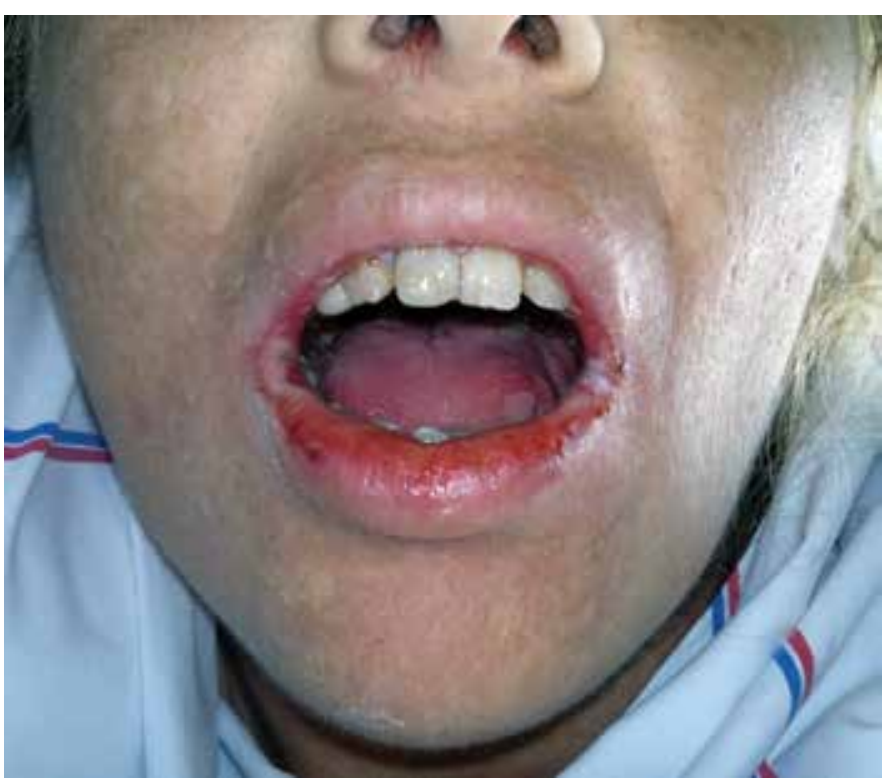

Figure 1. Macular rash on the chest and neck area

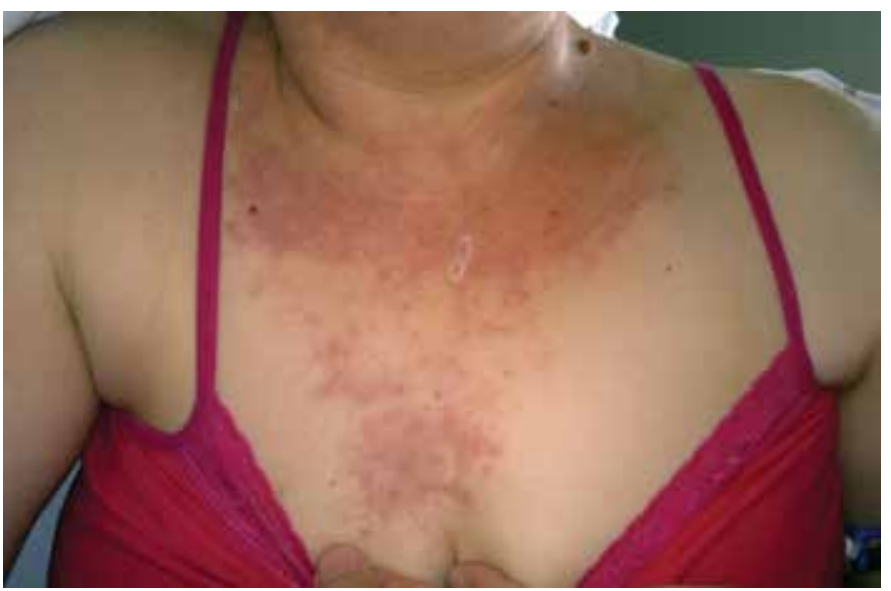

Figure 2. Oral lesions and mucositis detected her $\mathrm{Hb}$ level was $6.2 \mathrm{gr} / \mathrm{dL}$ and the white blood cell number was $1600 / \mu \mathrm{L}$ (Table 1). Lesions in the oral mucosa and skin increased and the diarrhea worsened. She was transferred to the intensive care unit. The serum level of MTX was high (more than 2 picograms/L). Calcium folinate infusion, and erythrocyte (4 units), thrombocyte (6 units) replacement and intravenous hydration and nutrition, and broad spectrum antibiotics were started. Sodium bicarbonate was administered via intravenous infusion to increase the excretion of the MTX alkalization of urine. Despite the supplementary treatment and folinic acid treatment, high levels of MTX continued and her cytopenic clinical state worsened. Plasmapheresis was considered for lowering MTX levels because glucarpidase (carboxypeptidase G2) is not available in Turkey. The level of MTX decreased after performing plasmapheresis. The patient's symptoms and clinical findings regressed. After 18 days of hospitalization (one week intensive care unit) she was discharged from hospital with no symptoms.

\section{Discussion}

MTX is a cheap and minimally toxic drug in low doses and is widely used in patients with non-ruptured ectopic pregnancy in suitable clinical conditions. Before treatment with MTX, a viable intrauterine pregnancy must be excluded; $\beta$-hCG levels, renal and liver function tests, and a complete blood count should be checked. MTX treatment has single-dose and multiple-dose protocols. Adverse effects can be seen more frequently in multidose protocols $(7)$. The adverse effects of MTX are caused by irreversible inhibition of the enzyme dihydrofolate reductase in purine synthesis. Decreases in blood cells and hemorrhage from the gastrointestinal tract are due to the effect on rapidly dividing cells of the bone marrow and intestinal tract(11). Severe adverse effects are infrequent in MTX treatment for ectopic pregnancy. The potential severe adverse effects of MTX treatment are hepatotoxicity, pulmonary toxicity, risk of infection, myelosupression, and nephrotoxicity. Hepatotoxicity results from direct damage to hepatocytes or in patients with concomitant viral hepatitis. Minor aminotransferase elevations

Table 1. Complete blood count values

\begin{tabular}{|c|c|c|c|}
\hline & $\mathrm{Hb}(\mathrm{gr} / \mathrm{dL})$ & $\mathrm{WBC}(/ \mu \mathrm{L})$ & $\operatorname{PLT}(/ \mu \mathrm{L})$ \\
\hline Admission day & 6.4 & 2000 & 104000 \\
\hline Admission day & 6.2 & 1600 & 106000 \\
\hline $1^{\text {st }}$ day & 7.3 & 1800 & 105000 \\
\hline $1^{\text {st }}$ day & 7.8 & 1200 & 91000 \\
\hline $2^{\text {nd }}$ day & 7.7 & 700 & 65000 \\
\hline $3^{\text {rd }}$ day & 7.1 & 500 & 47000 \\
\hline $4^{\text {th }}$ day & 6.7 & 300 & 37000 \\
\hline 10th day & 9.6 & 24000 & 91000 \\
\hline
\end{tabular}

Hb: Hemoglobin, WBC: White blood cells, PLT: Platelet 
are common but hepatic steatosis, fibrosis, and cirrhosis are seen rarely. For this reason, screening for hepatitis B and hepatitis $C$ virus infection and hepatic enzymes should be performed before initial therapy. MTX is an immunomodulatory but not significantly immunosuppressive agent. Myelosuppression is the major dose-limiting adverse effect of high- dose MTX, but it is infrequent in low-dose therapy. Hematologic toxicity associated with macrocytic red blood cells may be seen, but a more serious abnormality is the development of pancytopenia(12). Therefore, guidelines from the American College of Rheumatology recommend that a routine peripheral complete blood should be performed every four weeks in rheumatoid arthritis treatment ${ }^{(13)}$. Nephrotoxicity due to MTX rarely occurs in treatment with high doses. A slight decrease in creatinine clearance can be seen even at low, weekly doses used in rheumatoid diseases(14). Development of myelosuppression and mucositis such as MTX- related toxicity risk, is highest in patients with prolonged exposure to high levels of plasma MTX concentrations. Glucarpidase, a bacterial enzyme, is used for a rapid decrease of plasma MTX levels, which hydrolyses MTX to its inactive metabolites. The greatest benefit is achieved with glucarpidase when plasma MTX concentrations are high(15). Low-dose MTX is used in the medical treatment of ectopic pregnancy. Severe toxicity is an unexpected condition. In the present case, two doses of MTX were given one week apart but severe toxicity occurred. Compared with other treatment indications of MTX, the dose was very low but the subsequent adverse effects were detrimental and life threatening. Although the patient had no renal insufficiency, a high serum level of MTX was detected. Intensive care unit treatment and folinic acid replacement failed. Fortunately, the patient's signs and symptoms regressed with plasmapheresis. In review of the literature, severe toxicity due to MTX treatment for ectopic pregnancy was reported in a patient with renal insufficiency but severe toxicity in a healthy woman has not been reported(2). In conclusion, unexpected toxicity with MTX should be kept in mind during use of this simple treatment.

\section{Ethics}

Informed Consent: Consent form was filled out by participant. Peer-review: Externally peer-reviewed.

\section{Authorship Contributions}

Surgical and Medical Practices: Mehmet Vural, Sunullah Soysal, Concept: Mehmet Vural, Sunullah Soysal, Design: Begüm Ylldıhan, Mehmet Vural, Data Collection or Processing: Sunullah Soysal, Gökçe Anık İlhan, Analysis or Interpretation: Begüm Yıldızhan, Gökçe Anık İlhan, Literature Search: Sunullah Soysal, Gökçe Anık İlhan, Writing: Sunullah Soysal.

Conflict of Interest: No conflict of interest was declared by the authors.
Financial Disclosure: The authors declared that this study has received no financial support.

\section{References}

1. Cohen A, Zakar L, Gil Y, Amer-Alshiek J, Bibi G, Almog B, et al. Methotrexate success rates in progressing ectopic pregnancies: a reappraisal. Am J Obstet Gynecol 2014;211:128 e1-5.

2. Willner N, Storch S, Tadmor T, Schiff E. Almost a tragedy: severe methotrexate toxicity in a hemodialysis patient treated for ectopic pregnancy. Eur J Clin Pharmacol 2014;70:261-3.

3. Bleyer WA. The clinical pharmacology of methotrexate: new applications of an old drug. Cancer 1978;41:36-51.

4. Barnhart KT, Gosman G, Ashby R, Sammel M. The medical management of ectopic pregnancy: a meta-analysis comparing "single dose" and "multidose" regimens. Obstet Gynecol 2003;101:778-84.

5. Guvendag Guven ES, Dilbaz S, Dilbaz B, Aykan Yildirim B, Akdag D, Haberal A. Comparison of single and multiple dose methotrexate therapy for unruptured tubal ectopic pregnancy: a prospective randomized study. Acta Obstet Gynecol Scand 2010;89:889-95.

6. Lipscomb GH, Bran D, McCord ML, Portera JC, Ling FW. Analysis of three hundred fifteen ectopic pregnancies treated with single-dose methotrexate. Am J Obstet Gynecol 1998;178:1354-8.

7. Barnhart KT, Gosman G, Ashby R, Sammel M. The medical management of ectopic pregnancy: a meta-analysis comparing "single dose" and "multidose" regimens. Obstet Gynecol 2003;101:778-84.

8. Kelly H, Harvey D, Moll S. A cautionary tale: fatal outcome of methotrexate therapy given for management of ectopic pregnancy. Obstet Gynecol 2006;107:439-41.

9. Teal SB. A cautionary tale: fatal outcome of methotrexate therapy given for management of ectopic pregnancy. Obstet Gynecol 2006;107:1420-1; author reply 1.

10. Willner N, Storch S, Tadmor T, Schiff E. Almost a tragedy: severe methotrexate toxicity in a hemodialysis patient treated for ectopic pregnancy. Eur J Clin Pharmacol 2014;70:261-3.

11. Calabresi P, Chabner BA. Antineoplastic agents, chapter 52. In: Gilman A, Goodman LS, Goodman A editors. The pharmacological basis of therapeutics. 8th ed. New York: Macmillan; 1990. p. 1275-6.

12. Gutierrez-Urena S, Molina JF, Garcia CO, Cuellar ML, Espinoza LR. Pancytopenia secondary to methotrexate therapy in rheumatoid arthritis. Arthritis Rheum 1996;39:272-6.

13. Saag KG, Teng GG, Patkar NM, Anuntiyo J, Finney C, Curtis JR, et al. American College of Rheumatology 2008 recommendations for the use of nonbiologic and biologic disease-modifying antirheumatic drugs in rheumatoid arthritis. Arthritis Rheum 2008;59:762-84.

14. Kremer JM, Petrillo GF, Hamilton RA. Pharmacokinetics and renal function in patients with rheumatoid arthritis receiving a standard dose of oral weekly methotrexate: association with significant decreases in creatinine clearance and renal clearance of the drug after 6 months of therapy. J Rheumatol 1995;22:38-40.

15. Schwartz S, Borner K, Muller K, Martus P, Fischer L, Korfel A, et al. Glucarpidase (carboxypeptidase g2) intervention in adult and elderly cancer patients with renal dysfunction and delayed methotrexate elimination after high-dose methotrexate therapy. Oncologist 2007;12:1299-308. 